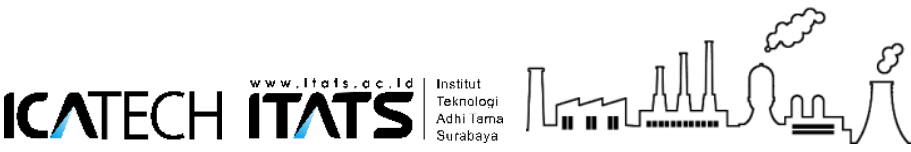

The $1^{\text {st }}$ International Conference on Advanced Engineering and Technology - 2018

\section{Mobile System Application for Tourist Guide in Surabaya}

\author{
D P Hapsari ${ }^{1}$, W M Rahmawati ${ }^{1}$ and D H Sulaksono ${ }^{1}$ \\ ${ }^{1}$ Institut Teknologi Adhi Tama Surabaya, Indonesia \\ dian.puspita@itats.ac.id
}

\begin{abstract}
Surabaya as the second largest city in Indonesia has been nominated as 12 cities with MICE (Meeting, Incentive, Conference, Exhibition) development. This causes the government of Surabaya concerns about the development of tourism such as history, education and maritime tourism. The biggest revenue of government came from trading sector, hotel, restaurant, and transportation. One of important things on developing tourism sector is the ease to access information of the tourism site. The infrastructure already completed by internet access as a smart city. All needs can be found online to save money. The implementation can be found in many fields, such as education, administrations, and tourism as the implementation of internet of thing. This research's goal is to design mobile system based on android smartphone for Surabaya tour guide. The system provides GPS technic to give tourism information and to manage tourism site effectively. This system gives recommendation of the MICE place which is suitable for the user based on their requirement. TOPSIS algorithm will be used to rank the recommendation. Index Terms-Android; Recommender system; TOPSIS; Tour guide application.
\end{abstract}

\section{Introduction}

Surabaya as the second largest city in Indonesia has been nominated as 12 cities with MICE (Meeting, Incentive, Conference, Exhibition) development. This causes the government of Surabaya concerns about the development of tourism such as history, education and maritime tourism. The government gives opportunity for companies to develop and provide facilities. Most of companies are hotels, meeting room facilities, transportation services, travel tourist service and incentive. The biggest revenue of government came from trading sector, hotel, restaurant, and transportation.

As the MICE city must be equipped with places, (1) Meeting: the place of meeting a small scale and normally under 1000 people. (2) Incentive: place can give stimulation of the meeting a small and big scale, generally is development motivation business with capacity 500 - 2500 people. (3) Convention: the meeting place between institutional in a large scale attended 1000- 2500 people. (4) Exhibition: a place to hold an exhibition in small to big scale indoor or outdoor. Surabaya also nominated as smart city, which almost every activity uses internet. Many internet points can be found in Surabaya. The citizen can easily use them to access anything they want. The citizen of Surabaya came from many different regions.

The tourism industry is one of the fastest growing economic sectors, which involves many online applications in every phase of its activities, ranging from travel planning, booking accommodation or hotel accommodation. There are many people who book accommodation online because it is faster, cheaper and they get detailed information about hotel facilities and location. Along with the 
development of online ordering applications, sites that present reviews in the field of tourism are also developing. With so many sites that provide ratings and feedback, it's impossible to read them all and, it becomes very difficult to find relevant information for someone to get the overall picture. Some sites only provide a ranking system (based on stars or numbers). So that the current excess information becomes a new problem.

There are many research about tourist guide and recommender city and still developing till now [1][2] and [3]. The goal of this research is to design mobile system for android smartphone for Surabaya tour guide. This system will use GPS to locate the point of users. The system will give information to the users about hotels, restorants, and MICE place in Surabaya so they can use their time in Surabaya effectively.

This system will give recommendation to users about hotels, restaurant or MICE place based on their requirement and interest. The recommendation will use TOPSIS algorithm to rank the available places. TOPSIS is one of the multicriteria decision-making methods first introduced by Yoon and Hwang 1981. TOPSIS uses the principle that the chosen alternative must have the closest distance from the positive ideal solution and farthest from the negative ideal solution from a geometric point of view using Euclidean distance to determine the relative proximity of an alternative with the optimal solution. Positive ideal solutions are defined as the sum of all the best values that can be achieved for each attribute. TOPSIS considers both distance to positive ideal solutions and distance to negative ideal solutions by taking relative proximity towards positive ideal solutions. Based on comparisons with relative distances, alternative priority arrangements can be achieved.

This method is widely used to solve practical decisions. This is because the concept is simple and easy to understand, the computation is efficient, and has the ability to measure relative performance and decision alternatives. This method is also similar to cluster analysis, as part of multivariate attribute decision making methods. The recommendation will be based on the distance of users, price, and the rating of the place.

\section{Theoritical Theorm}

\subsection{Internet of Thing}

Term internet of thing first used by Kevin Ashton in 1999, a concept of connecting anything in anytime and anyplace. The smart object can identify, locate, track, monitor and manage anything. IOT is considered as new wave of information technology following computer, internet, and mobile communication network. The application can be intelligent transporation, helath care, etc [4].

\subsection{Global Positioning System (GPS)}

Global Positioning System is a satellite based navigation system that correlated each other on their orbit. To obtain someone's position we need GPS receiver to get signal from GPS satellite. The position then convert to coordinate points to show longitude and altitude location [5]. GPS receiver contains many integrated circuit makes them easy to use and low cost.

\subsection{Location Based Service (LBS)}

Location Based Service has abilities to find geographic location and provide service based on the found location. The concept of LBS is produce service information about the position of user [6]. Therefore the obtained information has the high value for the LBS service provider. Provider offers instant information what the user's need and relevant to their location. LBS can be classified by local information, traffic and tracking information, and general service.

Local information allows user to find services around them. Traffic and tracking information focuses on tracking of asset and human. General services do not provide information to user but uses the data location of the user.

There are four main components to support LBS: mobile device, communication network, positioning component, and provider and application. Mobile device is a tool for user to get 
information. The information can be text, sound, image, etc. Mobile device can be a smartphone, laptop and PDA. Communication network is used to send data from user's mobile device to provider and send information from provider to user. Positioning component provides services from provider based on the location of the users. Providers are LBS component that provide services for users. When the user ask for service to point their current position, the application and service provider will process their request [2].

\subsection{TOPSIS}

Technique for order preference by similarity to ideal solution (TOPSIS) is a concept to choose the shortest distance to ideal solution as the chosen alternative [7]. To find the distance from the ideal solution can be measured by Euclidean distance. The method of TOPSIS consist of following steps: Step1. Create a matrix consisting of $m$ alternatives and $n$ criteria as follow

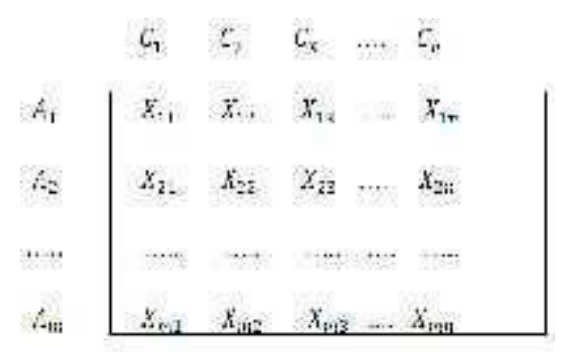

Step 2. Calculate the normalized decision matrix with the equation below.

$$
N_{i j} \sqcap x_{i j} / / \quad \overline{\urcorner_{i}^{m}{ }^{m} x_{i j}{ }^{2}}, i \sqcap 1, \ldots, m, j \sqcap 1, \ldots, n
$$

Step 3. Calculate the weighted normalized decision matrix.

$\begin{array}{lll} & { }^{V} i j\left\ulcorner{ }^{N} i j{ }^{W} j\right. & , i \sqcap 1, \ldots, m, j \sqcap 1, \ldots, n \\ \text { Where } & W_{j} \text { is the } & \text { weight of the } i \text { th attribute } \\ \urcorner_{j^{n}{ }^{-1}{ }^{W} j} & \sqcap 1\end{array}$

and

Step 4. Determine to best and the worst alternatives.

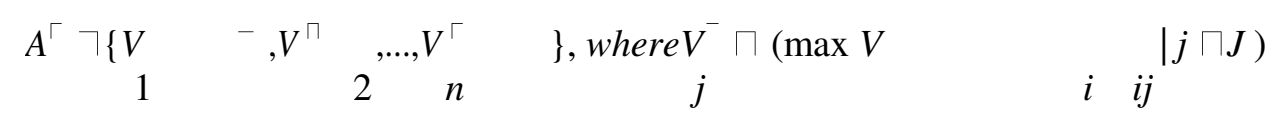

And

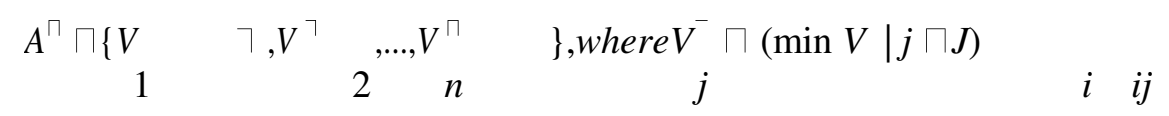

Where $\quad J$

Step 5. Calculate the distance between each target

alternative and the best (eq 5) and worst (eq 6) alternatives. 


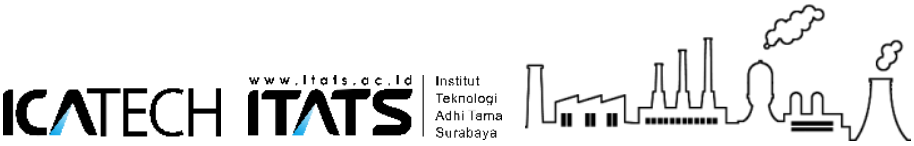

The $1^{\text {st }}$ International Conference on Advanced Engineering and Technology - 2018

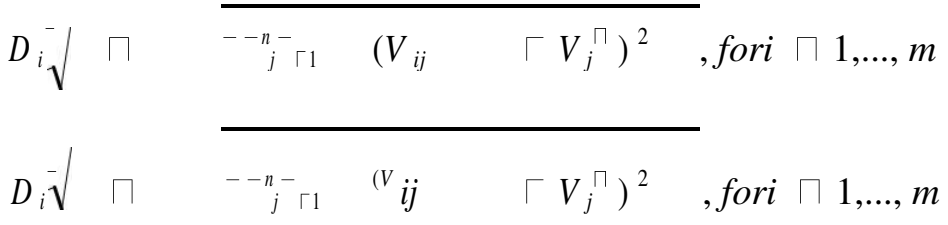

Step 6. Calculate the similirity to the worst condition

$$
R_{i} \quad \sqcap D_{i}^{-} /\left(D^{-} \sqcap D^{-}\right), i \sqcap \underset{i}{1} \underset{i}{1, \ldots, m} \text { and } R \in[0,1]
$$

Step 7. Rank the preference order in decreasing order.

\subsection{Mobile Tour System}

The system is mobile based so users can access everywhere with their gadget. This system has four main functions: Map and routing: basic map information. Show the map of place the user want to find. Tracking and information: function to ease user to find location and information about places. The information are about the picture of the place, rating, comment, and the price of the place. Booking: user can book easily some place that they desire. This system integrated with the system of the chosen place. Recommendation: user can view some recommendation place for their needs.

Steps to build mobile tour system: Collect location data and information about places that provide MICE in Surabaya. Design map model and route for the application. Design application framework for mobile tour system. Implement application mobile tour system. Test the application

\section{System Design}

The Conceptual Data Model (CDM) of the system can be seen in Figure 1. CDN shows the database desain which is used in this system.

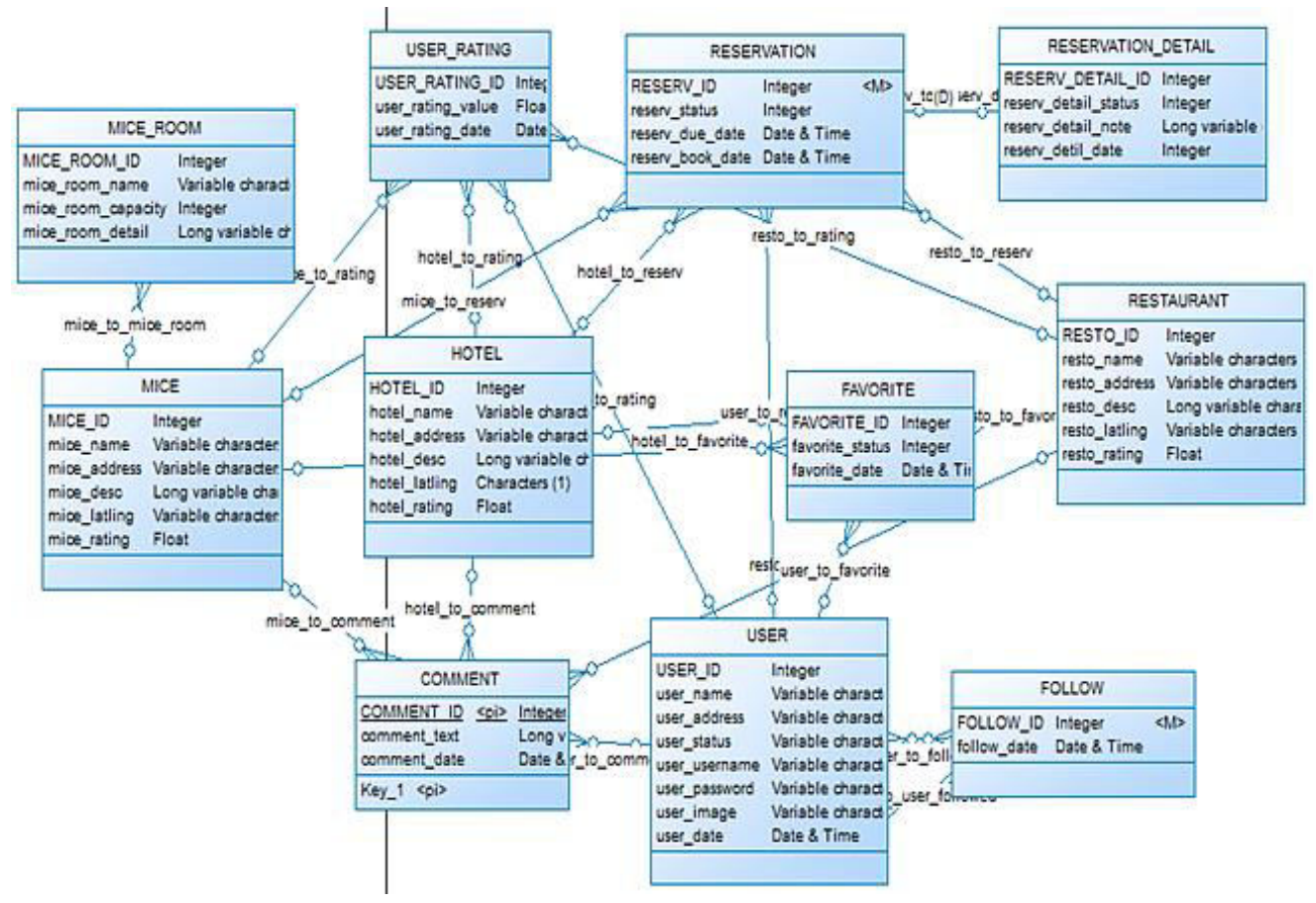

Figure 1. Conceptual Data Model of database system 


\section{ICATECH ITATS =}

The $1^{\text {st }}$ International Conference on Advanced Engineering and Technology - 2018

The first design of application that will be explained is shown in Figure 2. To acess the application, first, user must log in to the system. If they do not have account yet, they must sign up. Sign up can via Facebook application, Google, or by manual input.

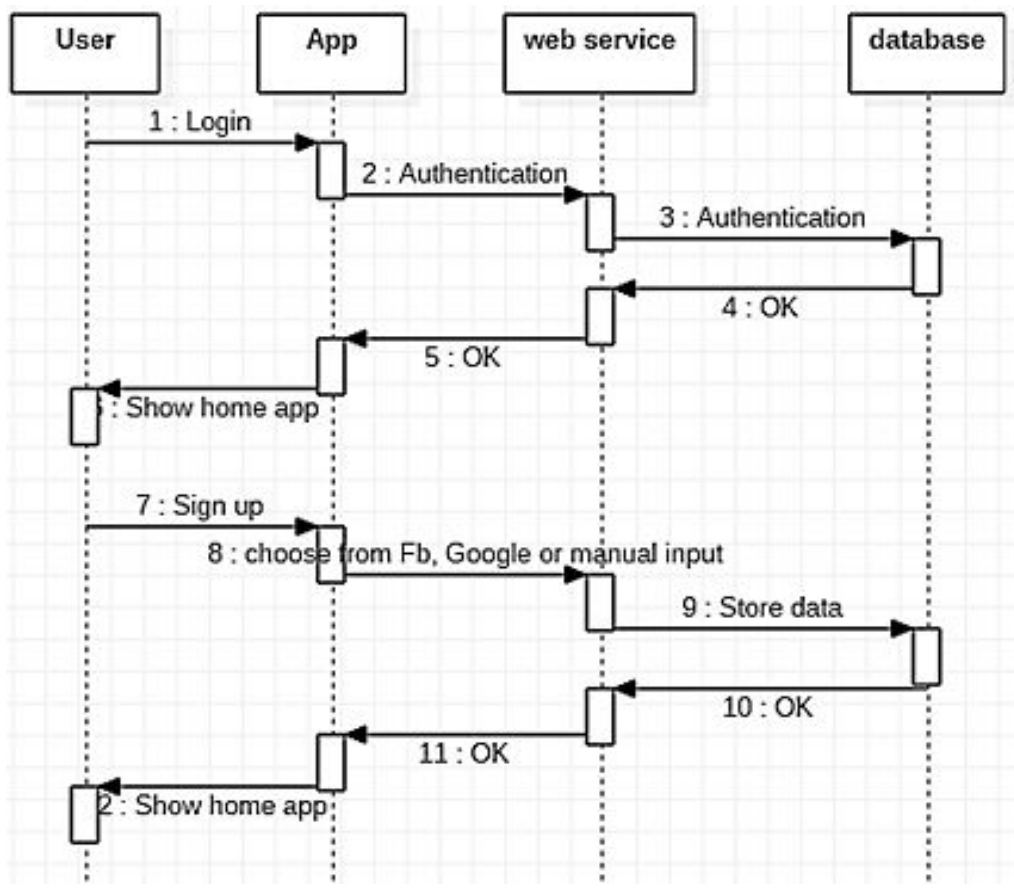

Figure 2. Sequence diagram of login and sign up

Next, user can choose what menu they like, are they need hotels, resto or MICE place. For example they need a hotel information. The sequence diagram when user choose hotel menu and filter them, can be seen in Figure 3. The sequence diagram for other choice is adjusted.

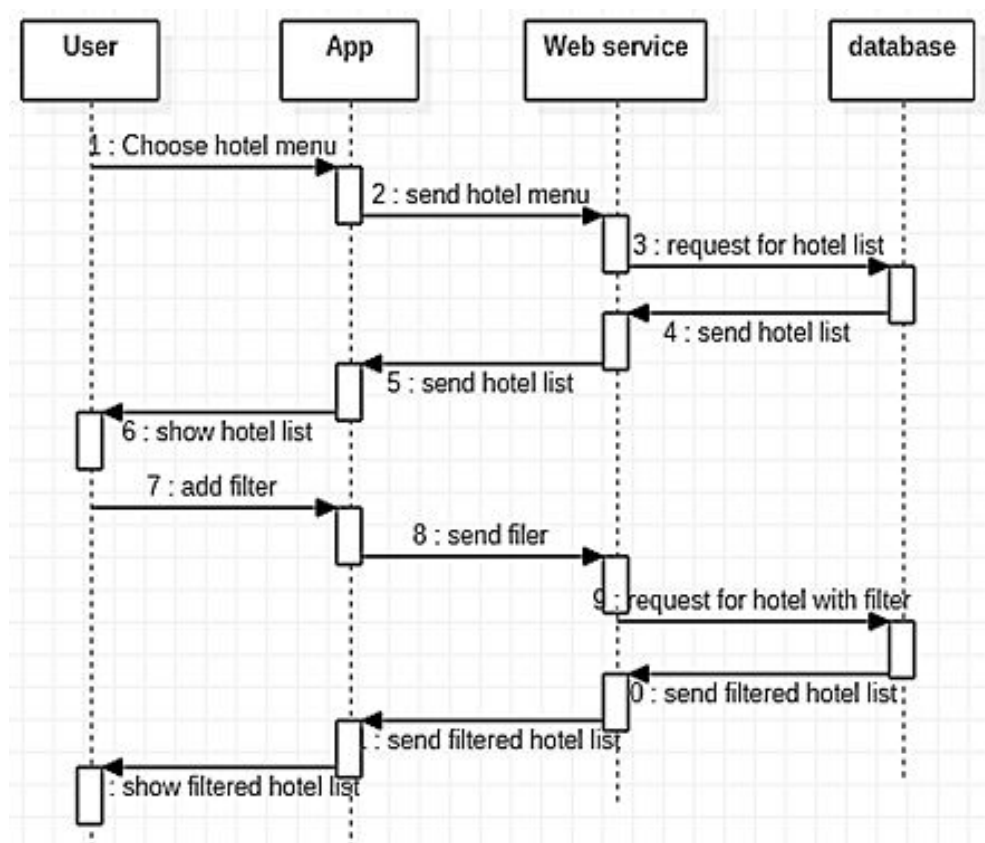

Figure 3. Sequence diagram if choose hotel menu 


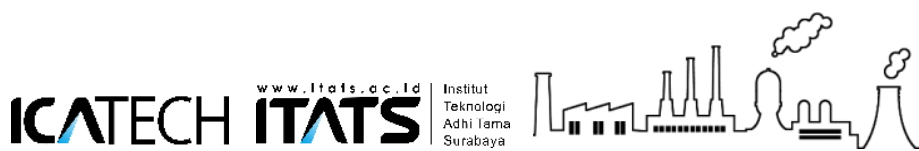

The $1^{\text {st }}$ International Conference on Advanced Engineering and Technology - 2018

\section{Application Implementation}

To use the application, first thing to do by user is signing in. If they don't have account yet, they must sign up. User can sign up via Facebook or Google acount. In user setting, there are some menus. The explanations of the menus as follows: My Favorite: a list of user's favorite places. Reservation: a list of place that have been reserved by user. Status follow: a list of other users who follow the user. Notification: notification about recent activity and notification about other user's activity whom follows by the user. Address setting: form to change the current address. Change password: to change current password. Change data: form to change user's data profile like profile picture and profile name. Log out: to log out from the application.

User can choose whether want to find hotels, restos, or MICE places. For each available hotel, resto or MICE place can be seen in Figure 4. User can do filter about place they want. The available filter is based on price, rating, distance, or choose by system recommender. The system reccomender will give recommendation by the combination of price, rating and distance with TOPSIS algorithm that already mention above.
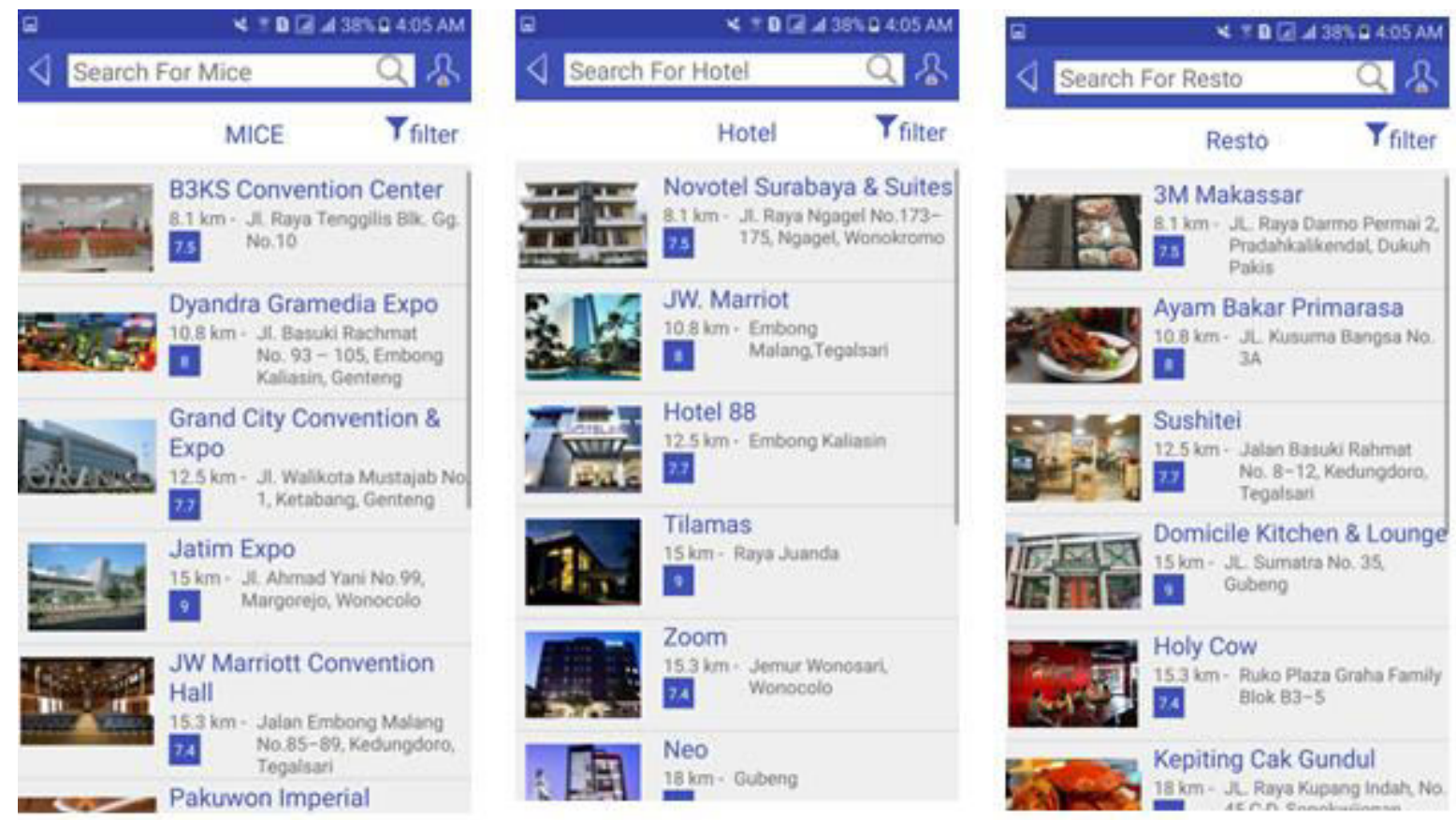

Figure 4. Available hotel, resto or MICE place can be seen

When user want to explore one of they place they want, the application will show the detail of the place . It can be seen that detail of place have 4 menus and 1 show location button: Favorite: user can make the viewed place as their favorite place. All user's favorite place can be seen in user setting. Reservation: in this menu user can rserve the current place. Comment: to show users comments about the current place. Rating: to see the rating of the place and give rating. Show location: to show the location in maps. It also can show navigation from certain place.

\section{Conclusion}

Mobile tour system as the result of this research is work to ease the tourist in Surabaya. Users can access detail information about hotels, restos, MICE places in Surabaya based on their want and needs. This application also give the user recommendation hotels, restos, and MICE place which is based on price, distance, and rating. With this recommendation, user can easily find the best place for them in Surabaya. It really saving their time. Users also can reserve the hotel or MICE place by the application. 


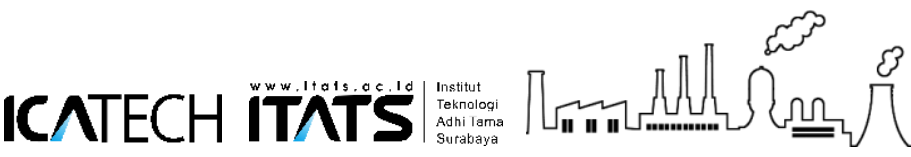

The $1^{\text {st }}$ International Conference on Advanced Engineering and Technology - 2018

\section{References}

[1] M. J. Kaur and P. Maheshwari, "Smart Tourist for Dubay City," in International Conference on Next Generation Computing Technologies, 2016.

[2] J. Borras, A. Moreno, and A. Valls, "Intelligent tourism recommender system: A survey," in Expert System with Application, 2014, pp. 7370-7389.

[3] D. Gavalas, C.Konstantopoulus, K. Mastaka, and G. Pantziou, "Mobile Recommender system Tourism," in Journal of Network and Computer Applications, 2013.

[4] W. Mingjun and et al, "A Research on Experimental System for Internet of Things Major and Application Project," IEEE, 2012.

[5] S. Baja, Perencanaan Tata Guna Lahan dalam Pengembangan Wilayah (Pendekatan Spasial dan Aplikasinya). Makassar: Andi Offset, 2012.

[6] Riyanto, Sistem Informasi Geografis Berbasis Mobile. Yogyakarta: Gava Media, 2010.

[7] P. K. Parida and S.K. Sahoo, "Multiple Attribute Decision Making Approach by TOPSIS Technique," Int. J. Eng. Res. Technol., vol. 2, 2013.

\section{Acknowledgment}

We like to thank to our instantion Institut Teknologi Adhi Tama to give opportunity and facilities to this research. And we want to thank to Ministry of Research, Technology and Higher Education of the Republic of Indonesia for the trust and financial support to make this research possible. 